\title{
Experiment on Concrete with Partial Replacement of Sand with Alternate Green Materials
}

\author{
T.M. Menaka, P. D Arumairaj, Antony Godwin, M.Yuvaraj
}

\begin{abstract}
In recent decades, there is a sprut in the growth of the construction industry. Aggregates are one of the main ingredients for making concrete. Depletion of natural resources of sand and the effect of mass production of cement on sustainable environment, need studies on the use of alternative materials. On the other hand, dumping of wastes from the industries are piling up resulting in the pollution of the environment. By considering the above facts, severe studies are focused on partial replacement of river sand with alternatives like copper slag, steel slag, quarry dust, etc., The outcome of these studies shows that the alternate materials enlarge the mechanical and durability properties of concrete. The optimum dose of alternate materials to replacement of sand is evaluated. In this paper, technical papers published by researchers are studied, discussed and compared
\end{abstract}

Keywords- fibrous concrete, partial replacement, green materials,

\section{INTRODUCTION}

The availability of sand has become scarce. Due to this, the cost of sand has enormously increased. In addition constant quarrying of sand has affected the ground water table level. The GWT has greatly reduced to alarming proportion when it is combined with deficiency in rain. This has telling effect on the environment. It is with the duty of every civil engineer to ensure sustainability environment by saving natural resources. This leads to intensive research to find alternative materials in the place of sand to be used in concrete without compromising on its quality and performance. Many researchers has attempted numerous alternative material by conducting various studies on its strength and durability characters.

At the same time, many waste materials and bi-products from the industries are dumped as waste. This leads to health hazards to nearby habitants and affects the overall environment. It pollutes soil, ground water and air. There is an increase in need to study the properties of these waste materials and to see the feasibility of the materials to replace sand upto an optimum need of requirement by conducting experiment of investigation

Revised Manuscript Received on April 12, 2019.

T.M. Menaka, Research Scholar MAW Department of Civil Engineering Karunya Institute of Technology \&Science Coimbatore, T.N India..

P. D Arumairaj, Professor, Department of Civil Engineering Karunya Institute of Technology \&Science Coimbatore, T.N, India.

Antony Godwin, Assistant Professor, Department of Civil Engineering Karunya Institute of Technology \&Science ,Coimbatore, T.N, India.

M.Yuvaraj, Geotechnical \& Structural Consultant Alzum Geocivil Integrated Services Coimbatore, T.N, India.

\section{LITERATURE REVIEW}

Ronaldo S Gallardo et al.(2006), have investigated on the feasibility of using paper mill sludge, as an alternative material for fine aggregate in fresh concrete for low cost budgeted project. various mix proportion of specimen were made and tested for hardened concrete. an experimental study was carried out using paper sludge, super plasticizer, conducted compression and spit tensile tests. comparison of physical and chemical properties of sand and paper sludge and evaluated the effect of admixture on the water content and density of concrete with paper mill sludge is studied. the most suitable mix proportion is the $5 \%$ to $10 \%$ replacement of paper sludge to fine aggregates. the compressive and splitting tensile strength decreases as the percentage replacement increases with the addition of admixtures.

Parveen et al (2013), studied effect of variation of polypropylene fiber ranges from $0.1 \%$ to $0.4 \%$ with $0.8 \%$ steel fiber. Cubes, cylinders \& beams have been cast with varying percentages of fiber volume fraction and conducted compression, flexural and split tensile tests. It is observed that the optimum dosage of polypropylene fiber fraction is $0.3 \%$.

Romanbabu M. Oinam et al (2013), To observe the change/enhancement in the strength, stiffness, ductility and energy dissipation capacity of the beam column joints by using fiber materials. The three nos. of one third $(1 / 3 \mathrm{rd})$ scaled beam-column joints have been cast with plain RC and RC fibers and tested by applying cyclic load. The tests were conducted by using servo hydraulic actuator (MTS made) of $100 \mathrm{kN}$ capacity. The recorded data were plotted to draw hysteresis loop. The result were compared in various plot like envelope curve, stiffness, energy dissipate and ductility. The addition of fibers plays an important role for arresting, delaying and propagating of cracks. There was remarkable increase in load carrying capacity due to addition of fiber (ranging from $8.95 \%$ to $17.37 \%$ ). The initial stiffness for fibers specimen increased tremendously (ranging from $27.9 \%$ to $43.2 \%$ ). The energy dissipation increased considerably for fibers specimens (ranging $12.62 \%$ to $35.83 \%$ ). The ductility increased tremendous for fibers specimens (ranging $99.4 \%$ to $105 \%$ ). It was observed that performance of fiber specimens in term of all the above parameters were better than the plain specimen.

Published By:

Blue Eyes Intelligence Engineering 
Eldhose M Manjummekudy et al(2014), made an attempt to use eco sand, weathered crystalline rock and granulated blast furnace $\operatorname{slag}(\mathrm{GBS})$ as fine aggregate replacement in concrete. A literature review was made on the properties of surrogate materials and their behaviors on different proportion were studied. Comparing to the all the above material weathered crystalline rock having more workability. The compressive strength of normal mix is lesser when compared Weathered crystalline sand and maximum value was found at $100 \%$ replacement , $75 \%$ of eco sand replacement, and $50 \%$ of GBS replacement for FA. On Split tensile test strength, it is found to be more in $100 \%$ weathered crystalline rock, $25 \%$ of eco sand. On flexural strength, it is found to be more in $100 \%$ weathered crystalline rock.

R. M. Saravana Kumar et al. (2014), studied the behavior of exterior beam column joint designed and detailed as per IS13920 with and without fiber. A seven story RCC framed structured building was modeled in STAAD Pro Software. The DL, IL, and lateral loading were done also columns, beams were designed in STAAD output and IN-House spreadsheet respectively. M60 HPC mix designed 1:1.6:2.03 and water cement ratio 0.32 with HRWR were espoused. It was investigate the load-deflection characteristics, ductility factor, load carrying capacity and stiffness characteristics of sub-assemblies of fiber reinforced high strength concrete beam column joint under cyclic loads through experimental study. To compare the behavior of all the specimens with the effect of steel fiber in the beam column joint under cyclic loads and also to compare the various parameters like stiffness, ductility and load carrying capacity. Under cyclic loading the effective application of steel fibers in the beam column joint concrete mix results, significantly improved joint behavior under seismic loading, in particular with an increased ductility and stiffness than conventional specimen. The effect of adding steel fibers influence the behavior of beam column joint by increasing the ductility characteristics and initial stiffness.

\section{RESULTS \& DISCUSSIONS}

Wengui Li et. Al (2015), evaluated the structural behavior of composite members with recycled aggregate concrete. Initially the structural behavior of RAC filled steel tubular columns and beams were reviewed. Followed by the evaluation of structural behavior of steel reinforced RAC member inclusive of column, beams, shear walls, slabs and finally the long term performances of composite members with RAC incorporating fire resistance, durability and seismic performance were observed.RAC is slightly lower compared with normal concrete ones, including RAC-filled steel tubular columns and beams, as well as steel reinforced RAC columns, beams, shear walls, and slabs. RAC filled steel tubular columns with recycled coarse aggregates have better fire resistance than those with recycled fine aggregates with the same replacement ratio. the loss of elastic modulus of hollow RAC filled steel tubular columns is more significant than that of solid RAC filled steel tubular ones during freeze-thaw cycles. Appropriate control of the axial compression ratio and stirrup ratio can improve the seismic performance of composite members.
T. Subramani et al. (2015), made an experimental investigation on partial replacement of sand with glass fiber with concrete. Various types of glass fibers were collected, their physical characteristic were studied, mix design was done. Based on the experimental study on overall performance it is found that $10 \%$ of glass fibers replacement shows the best results in FA.

T. Subramani et al. (2015), made an analytical and experimental study on bonded glass fiber reinforced polymer sheets with reinforced concrete beam using ANSYS program. FEM modeling was made and analyzed and find out that for beam analysis ANSYS software is effective.

Harish B A et al.(2016), conducted experimental study on M20 Grade cement concrete with crimped steel fiber. Mix design of 4 numbers were made and tested. The test results are compared with analytical reports. Strength parameters are increasing and while comparing with workability it is vice versa, by increasing the volume of crimped steel fiber.

Kaleem A. Zaidi et al (2016), compared different models of high strength confined at different temperature. Based on the residual strain model it is found to be observed that the empirical equation matches with the experimental results.

Flora Faleschini et al. (2017), conducted an experimental test on beam-column joint with Electric Arc Furnace (EAF) slag under cyclic loading. Three real scale RC exterior beam-column joints with similar geometry and reinforcement detailing were casted. Horizontal load was applied to the top of the column and observed displacement on the main frame. By following ACI374.1-05 test was conducted by reversed cyclic quasi-static with displacement control.The experimental results give a first indication about the potential use of EAF slag as recycled aggregate to produce structural concrete employed in structures subject to seismic actions.

Mr. Ashish Kumar Yadav et al (2017), evaluated the behavior of Polypropylene Fiber Reinforced Concrete for the improvement of Brittle nature of RCC beam in the Construction by studying the Compressive Strength, Split Tensile Strength and Flexural Strength of Concrete. Cubes cylinder, prism, structural member beams of polypropylene fiber were casted and their development in mechanical property of concrete (Grade M25 and M30) is assessed. Addition of polypropylene fibers have no significant effect on the compressive strength.Split tensile strength increases by about $18 \%$ for M25 grade of concrete with the addition of polypropylene fiber at $5 \mathrm{~kg} / \mathrm{m} 3$. Flexural strength shows higher value around $11 \%$ increment for M25 grade of concrete with the addition of $4 \mathrm{~kg} / \mathrm{m} 3$ of polypropylene fiber and decreases after further addition.Workability is observed to be decreasing with the addition of polypropylene fiber.The ultimate load carrying capacity of RCC beam increases upto $12 \%$ for M25 grade of concrete with the addition of $5 \mathrm{~kg} / \mathrm{m} 3$ of polypropylene fiber.

Shahab Samad et al(2017),studied The effects of the partial replacement of cement with GGBS on the engineering properties of concrete under different curing conditions. 4 number of mix proportions were done and tested. Partial replacement of cement by GGBS up to $50 \%$ 
has little impact on the compressive strength at 56 days, as the compressive strength achieved has a reasonable value for use in structural works. Strength gaining of concrete is rapid in summer when compared to winter.

Awadhesh Chandramauli et al (2018), studied mechanical properties of fiber (steel, glass, polymer) reinforced concrete with different weight fraction with respect to cement. Models were done on corresponding fiber replacement and tested. By using mixture of two or more fibres above 1.5 percent in concrete compressive strength do not affected but split tensile strength and flexural strength of concrete increase.

B. González-Fonteboa et al (2018), tries to collect and updates RC finding by proposing equation for defining $\mathrm{RC}$ performance in terms of mechanical strain, modulus of elasticity, creep and shrinkage. The lower the recycled aggregate ratio is, the lower the strength loss will be.According to the analysis of the relationship "RC's compressive strength-conventional concrete's compressive strength", the average reductions are 5\%,10\% and $13 \%$ for $20 \%, 50 \%$ and $100 \%$ replacement ratios, respectively. For the relation-ship between RC and conventional concrete, splitting tensile strength for different replacement ratios, the average reductions were $7 \%$ and $10 \%$ for low $(<50 \%)$ and high ratios (50-100\%), respectively.

Hubert Christopher et al (2018), Studied the behavior of glass fibre reinforced concrete with copper slag as a partial replacement of fine aggregate. Three sets of design mix are made and tested. Comparison between test results and analytical report are done. And found to be concluded that optimum value attained is $60 \%$ of copper slag with intrusion of glass fiber to FA.

Pengda Li et al (2018), studied the stress strain behavior Fiber Reinforced Polymer (FRP)- confined light weight concrete with varying types of aggregates. Initially Zhou et al. founded the stress strain behavior of carbon FRP confined light weight aggregate concrete where in only light weight coarse aggregates were adopted the self weight of concrete and reviled that ultimate strength and ductility capacity of LWAC could considerably enhanced by jacketing CFRP. This author extended the research by varying the various fine aggregated to light weight aggregate confined concrete. The confinement were tested as unconfined sample, 1-ply CFRP confined and 3-ply CFRP confined, compared with the previous author. Finally the conclusion is that the coarse aggregate governs the strength properties of FRP-confined concrete, and the fine aggregate mainly controls its ductility properties

\section{CONCLUSION}

Base on the literature reviews, it clearly seems that partial replacement of fine aggregates with paper sludge, steel fiber, copper slag, furnace slag, welding slag, polypropelene fiber, glass fiber, coir fiber, GGBFS, WBA, Quarry dust, foundry sand ,C\&DW, SFB, SGP, Eco sand, Geo-polymer, Steel slag, crimped steel fiber, electric arc furnace slag, basalt fiber, palm fiber, red mud were used and their physical and mechanical properties were observed. Some of the authors have taken the case of beam-column joint behavior in their research and approached FEM analysis by using ANSYS.

\section{REFERENCES}

1. Ronaldo S. Gallardo et al, "Structural Performance of Concrete With Paper Sludge As Fine Aggregates Partial Replacement Enhanced With Admixtures", Dec 2006, ResearchGate

2. Hamid Pesaran Behbahani et al, "Flexural Behavior of SteelFiber-Added-RC (SFARC) Beams With C30 And C50 Classes of Concrete", 2012 , International Journal of Sustainable Construction Engineering \& Technology (ISSN: 2180-3242), Vol 3, Issue 1

3. Sreekrishnaperumal Thanga Ramesh et al, "Use of furnace slag and welding slag as replacement for sand in concrete", International Journal of Energy and Environmental Engineering 2013

4. Parveen et al," Structural Behaviour of Fibrous Concrete Using Polypropylene Fibres", International Journal of Modern Engineering Research Vol.3, Issue.3, pp-599-603, May-June. 2013

5. Romanbabu M. Oinam et al, "Experimental Study on BeamColumn Joint with Fibres under Cyclic Loading", IOSR Journal of Engineering e-ISSN: 2250-3021, p-ISSN: 22788719 Vol. 3, Issue 7 (July. 2013), ||V2 || PP 13-23

6. Suresh Reddy S,"Utilization of Copper Slag as a Partial Replacement of Fine Aggregate in Concrete", International Journal of Mechanical Engineering and Computer Applications, Vol 1, Issue 7,, ISSN 2320-6349, December 2013

7. Akshay C. Sankh," Recent Trends in Replacement of Natural Sand With Different Alternatives", IOSR Journal of Mechanical and Civil Engineering (IOSR-JMCE), e-ISSN: 2278-1684, p-ISSN: 2320-334X PP 59-66, 2014

8. Eldhose M Manjummekudy et al.," Comparative Study on the Effect of Concrete using Eco Sand, Weathered Crystalline Rock Sand and GBS as fine Aggregate Replacement”, ISSN: 2278-0181,Vol. 3 Issue 10, October- 2014

9. R. M. Saravana Kumar et al., "Experimental Study on Behavior of Steel Fiber Reinforced High Strength Concrete Beam-Column Joint", International Journal of Engineering Research \& Technology (IJERT), ISSN: 2278-0181 Vol. 3 Issue 11, November-2014

10. Wengui $\mathrm{Li}$ et. al.," Structural Behaviour of Composite Members with Recycled Aggregate Concrete - an Overview", Advances in Structural Engineering Vol. 18 No. 62015

11. T.Subramani et al., "Experimental Investigation Of Partial Replacement Of Sand With Glass Fibre", International Journal of Application or Innovation in Engineering \& Management (IJAIEM), Volume 4, Issue 5, May 2015

12. T.Subramani, "Analytical Investigation Of Bonded Glass Fibre Reinforced Polymer Sheets With Reinforced Concrete Beam Using Ansys", International Journal of Application or Innovation in Engineering \& Management (IJAIEM), Volume 4, Issue 5, May 2015

13. Lei Zeng et al,"Cyclical Behavior of Concrete-Encased Composite Frame Joints with High Strength Concrete", Hindawi Publishing Corporation Advances in Materials Science and Engineering, Volume 2015, Article ID 873162

14. Sarita R. Khot, "An Experimental Study On Shear Behavior Of Steel Fiber Reinforced Concrete Beam"

15. A. Annadurai and A. Ravichandran, "Flexural Behavior of Hybrid Fiber Reinforced High Strength Concrete", IJST, Vol 9(1), January 2016.

16. S. Karthik et al, "Fatigue behavior of steel Fiber Reinforced Concrete - A Review", IRJET, Volume 03, Issue 04, April 2016 

MATERIALS

17. Harshitha et al, "Study on The Fibre Reinforced Concrete Using Steel Slag As The Coarse Aggregate Replacement", International Journal of Engineering Research, Volume 05, Sep-Oct 2016.

18. Harish B A et al., "Experimental Study on the M20 Grade Cement Concrete Containing Crimped Steel Fibres", IJSTEInternational Journal of Science Technology \& Engineering ,Volume 3 ,Issue 03 , September 2016

19. Kaleem A. Zaidi et al,"Postheated Model of Confined High Strength Fibrous Concrete", Hindawi Publishing Corporation, Advances in Civil Engineering Volume 2016, Article ID 5659817, 14 pages

20. A. Saadun et al, "Behavior of Polypropylene Fiber Reinforced concrete under Dynamic Impact Load", JEST, Vol. 11, No. 5, 2016

21. Flora Faleschini et al., "Experimental behavior of beamcolumn joints made with EAF concrete under cyclic loading" Engineering Structures 139 (2017) 81-95

22. K Prasanna et al., "Strengthening of beam - column joint with steel fibre reinforced concrete under seismic loading", IOP Conf. Ser.: Earth Environ. Sci. 80012040

23. Praveen Kumar. S et al., "Experimental Study On Structural Behaviour Of Beam Column Joint Using Geo-Polymer Concrete", International Journal of Civil Engineering and Technology (IJCIET) Volume 8, Issue 3, March 2017, pp. 688-698 Article ID: IJCIET_08_03_069

24. K Mohana Priya et al., "Analytical Study on The Behaviour of Beam Column Joint using basalt fiber under cyclic loading", International Journal of Civil Engineering and Technology (IJCIET), Volume 8

25. T.Subramani et al., "Strength Study On Fibre Reinforced Concrete Using Palmyra Palm Fibre Using FEM Software", International Journal of Emerging Trends \& Technology in Computer Science (IJETTCS), Volume 6, Issue 3, ISSN 2278-6856, May- June 2017

26. T.Subramani et al.,"Analytical Study Of $\mathrm{T}$ Beam Column Joint Using FEM Software", International Journal of Emerging Trends \& Technology in Computer Science (IJETTCS), Volume 6, Issue 3, May- June 2017 ISSN 22786856

27. M.P Sureshkumar et al., "Study on behaviour of rc beamcolumn joint using red mud and quarry dust as partial replacement for cement and fine aggregate", International Journal of Advanced Science and Engineering Research, Volume: 2, Issue: 2, June 2017 ISSN: 2455-9288

28. Mr. Ashish Kumar Yadav et al, "Properties of polypropylene Fiber Reinforced Concrete and Structural Behavior of beam", IJIRSET, Vol. 6, Issue 6, June 2017

29. Shahab Samad et al., "Strength development characteristics of concrete produced with blended cement using ground granulated blast furnace slag(GGBS) under various curing conditions", Sadhana Vol. 42, No. 7, July 2017, pp. 1203 1213

30. Balamurugan.R et al., "An Experimental Study on Flexural Behaviour of Reinforced Concrete Sandwich Beam By Varying the Aggregate In Tension Zone", (ICRTCETM-2017)

31. Benard Isojeh et al, "Fatigue behavior of steel fiber concrete in direct tension", ASCE, 10.1061, June 2017.

32. Awadhesh Chandramauli et al, "The Analysis of Plain cement Concrete for Future scope when mixed with Glass \& Fibres", IJCIET, Volume 9, Issue 1, January 2018

33. Shikha Shrivastava et al, "Behavior of Concrete Using the Hybrid Fiber with and without Fly Ash", IJIRST, Volume 4, Issue 9, February 2018

34. P Sravani Ramya Singam et al, "An Experimental study on Behaviour of Slurry Infiltrated Fibrous Concrete (SIFCON) Produced by Partial Replacement of Cement with Metakaolin and Fine Aggregate with Robosand", IJIRSET

35. [35] B. González-Fonteboa et al, "Recycled concrete with coarse recycled aggregate. An overview and analysis" Vol.
68, Issue 330, April-June 2018, e151, Materiales de ConstruCCión

36. Filip Grzymski et al, "Mechanical properties of fibre reinforced concrete with recycled fibres", Construction and Building Materials 198 (2019) 323-331

37. Hubert Christopher et al, "Study on Glass Fibre Reinforced Concrete with Partial Replacement of Fine Aggregate by Copper Slag" International Journal of Engineering Research \& Technology (IJERT), Special Issue - 2018

38. Pengda Li et al, "Effects of Aggregate Types on the StressStrain Behavior of Fiber Reinforced Polymer (FRP) Confined Light weight Concrete", Sensors 2018, 18, 3525; doi:10.3390/s18103525

39. T. V. Chandrasekhar et al, "Study on Shear Behaviour of steel and Polypropylene Fiber Reinforced Concrete Beam", IJPAM, Volume 119 No. 14, 2018, 285-290

40. Achudan et al, "Experimental Study on Coir Fiber Mixed Concrete", IJPAM, Volume 118, No 20, 2018

41. Noridah Mohamad et al, "Mechanical properties and flexure behavior of lightweight foamed concrete incorporating coir fiber", IOP, September 2018. 